\title{
TIMING OF PASSAGE DEVELOPMENT AND SEDIMENTATION AT CAVE OF THE WINDS, MANITOU SPRINGS, COLORADO, USA
}

\author{
ČASOVNO USKLAJEVANJE RAZVOJA JAMSKIH PROSTOROV \\ IN SEDIMENTACIJA V JAMI CAVE OF THE WINDS, MANITOU \\ SPRINGS, COLORADO, ZDA
}

\author{
Fred G. LUISZER ${ }^{1}$
}

\begin{abstract}
UDC 551.3:551.44:550.38

550.38:551.44

Fred G. Luiszer: Timing of Passage Development and Sedimentation at Cave of the Winds, Manitou Springs, Colorado, USA.

In this study the age of the onset of passage development and the timing of sedimentation in the cave passages at the Cave of the Winds, Manitou Springs, Colorado are determined. The amino acid rations of land snails located in nearby radiometrically dated alluvial terraces and an alluvial terrace geomorphically associated with Cave of the Winds were used to construct an aminostratigraphic record. This indicated that the terrace was $\sim 2 \mathrm{Ma}$. The age of the terrace and its geomorphic relation to the Cave of the Winds was use to calibrate the magnetostratigraphy of a 10 meter thick cave sediment sequence. The results indicated that cave dissolution started $\sim 4.5 \mathrm{Ma}$ and cave clastic sedimentation stopped $\sim 1.5 \mathrm{Ma}$.
\end{abstract}

Key words: Cave of the Winds, Manitou Springs, magnetostratigraphy, aminostratigraphy, land snails.

\section{.Izvleček UDK 551.3:551.44:550.38}

\author{
550.38:551.44
}

Fred G. Luiszer: Časovno usklajevanje razvoja jamskih prostorov in sedimentacija $v$ jami Cave of the Winds, Manitou Springs, Colorado, ZDA

Članek se osredotoča na začetek razvoja jamskih prostorov in časovno sosledje sedimentacije $\mathrm{v}$ jami Cave of the winds, Manitou Springs, Kolorado. V bližini jame se nahajajo aluvialne terase, $\mathrm{ki}$ so bile datirane $\mathrm{z}$ radiometrično metodo. $\mathrm{Z}$ geomorfološko metodo so bile povezane $\mathrm{z}$ jamo Cave of the Winds. V teh aluvialnih terasah so bili najdeni fosilni ostanki kopenskih polžev, na katerih so bile opravljene datacije $\mathrm{z}$ aminokislinami, ki so pokazale starost $\sim 2$ Ma let. Starost aluvialnih teras in njihova geomorfološka povezava $\mathrm{z}$ jamo Cave of the Winds, sta služila kot izhodišče za natančnejšo časovno umestitev 10 metrov debele sekvence jamskih sedimentov, ki so bili magnetostratigrafsko opredeljeni. Raziskava je pokazala, da se je raztapljanje v jami pričelo pred $\sim 4.5 \mathrm{Ma}$ leti, medtem ko se je odlaganje klastičnih sedimentov prenehalo pred 1.5 Ma let. Ključne besede: Cave of the Winds, Manitou Springs, ZDA, magnetostratigrafija, aminostratigrafija, kopenski polži.

\section{INTRODUCTION}

Cave of the Winds, which is $1.5 \mathrm{~km}$ north of Manitou Springs (Figure 1), is a solutional cave developed in the Ordovician Manitou Formation and Mississippian Williams Canyon Formation. Commercialized soon after its discovery in the1880s it has been visited by millions of visitors in the last 125 years. As part of an extensive study (Luiszer, 1997) of the speleogenesis of the cave the timing of passage development and sedimentation needed to be determined. The task of dating the age of caves has always been an enigma because dating something that has been removed is not possible. Sediments deposited in the cave passages, however, can be dated, which then can be used to estimate the timing of the onset of cave dissolution and when the local streams abandoned the cave.

\footnotetext{
${ }^{1}$ University of Colorado, Boulder, Department of Geological Sciences, Campus Box 399, Boulder, CO 80302, USA.

Received/Prejeto: 13.12 .2006
} 
A specially constructed coring device was utilized to core several locations in the cave. The natural remnant magnetization (NRM) of samples taken from the cores were use to construct a magnetostratigraphic record. This record by itself could not be used to date the age of the sediments because sedimentation in the cave stopped sometime in the past and part of the record was missing.

An alluvial terrace, which overlies the Cave of the Winds, is geomorphically related to the cave. The age of the alluvial terrace, which had not been previously dated, can be used to determine the age of the youngest stream deposited sediments in the cave. An abundant number and variety of land snails were found when this alluvium was closely searched. Biostratigraphy could not be used to determine the age of the terrace because all of the snail species found were extant, however, the amino acid rations of the snails collected from this terrace and nearby radiometrically dated terraces were used to construct an aminostratigraphy that was used to date the alluvium. Once the age of the terrace was determined the age of the youngest magnetic chron of the magnetostratigraphic record could be assigned thus enabling the dating of cave dissolution and sedimentation.

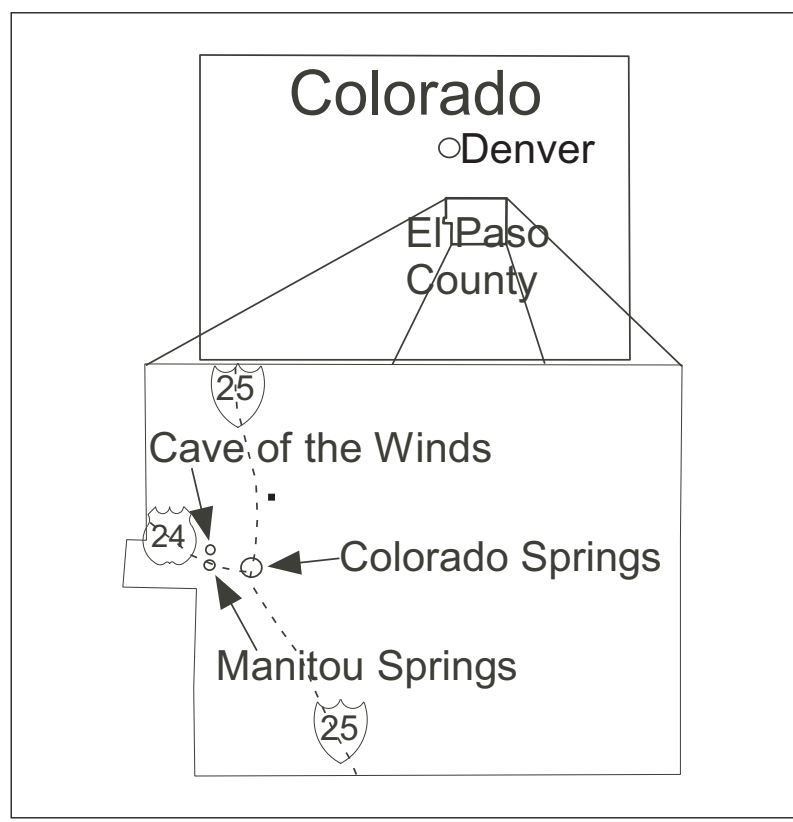

Fig. 1: Location of study area.

\section{FIELD AND LABORATORY PROCEDURES}

\section{Amino Acid Dating}

Snails were collected from outcrops of the Nussbaum Alluvium, and from younger radiometrically dated alluvia (Fig. 2) for the purpose of dating the Nussbaum Alluvium by means of amino-acid racemizatio.

Approximately $50 \mathrm{~kg}$ of sandy silt was collected at each site. To minimize sample contamination, washed plastic buckets and fresh plastic bags were used. The samples were loaded into containers with a clean metal shovel and with minimal hand contact. In the lab, the samples were disaggregated by putting them in buckets filled with tap water and letting them soak overnight.

The samples were then washed with tap water through $0.5-\mathrm{mm}$ mesh scree. Following air drying, the mollusks were hand picked from the remaining matrix by means of a small paint brush dipped in tap water. The mollusks were then identified. Only shells that were free of sediment and discoloration were selected for further processing. These shells were washed at least five times in distilled water while being sonically agitated. The amino-acid ratios were determined on a high-performance liquid chromatograph (HPLC) at the Institute of Arctic and Alpine Research (University of Colorado, Boulder).

\section{Paleomagnetism}

A coring device was used to sample the cave sediments at six cored holes in the Grand Concert Hall (Fig. 3). The core samples were obtained by means of a coring device in which a hand-powered hydraulic cylinder drives a stainless-steel, knife-edged barrel down into the sediments. Up to $40 \mathrm{~cm}$ of sediment could be cored each trip into the hole without sediment distortion. Samples were also collected from hand-dug pits at Mummys Alcove and Sniders Hall (Fig. 3). Additionally, samples were collected from a vertical outcrop in Heavenly Hall (Fig. 3). The pits and outcrops were sampled for paleomagnetic study by carving flat vertical surfaces and pushing plastic sampling cubes into the sediment at stratigraphic intervals ranging from 3.0 to $10.0 \mathrm{~cm}$. The samples were oriented by means of a Brunton compass.

The core barrel and all pieces of drill rod that attached to the barrel were engraved with a vertical line so that the orientation of the core barrel could be measured with a Brunton compass within $\pm 2^{\circ}$. A hand-operated hydraulic device was used to extract the sediment core from the barrels. As the core was extruded, a fixed thin wire sliced it in half, lengthwise. Plastic sampling cubes were then pushed into the soft sediment along the center line of the flat surface of the core half at regular intervals 
Figure 2. GEOLOGY MAP OF COLORADO SPRINGS AND MANITOU SPRINGS AREA

with locations of snail collection sites.

Geology adapted from Trimble and Machette, (1979).
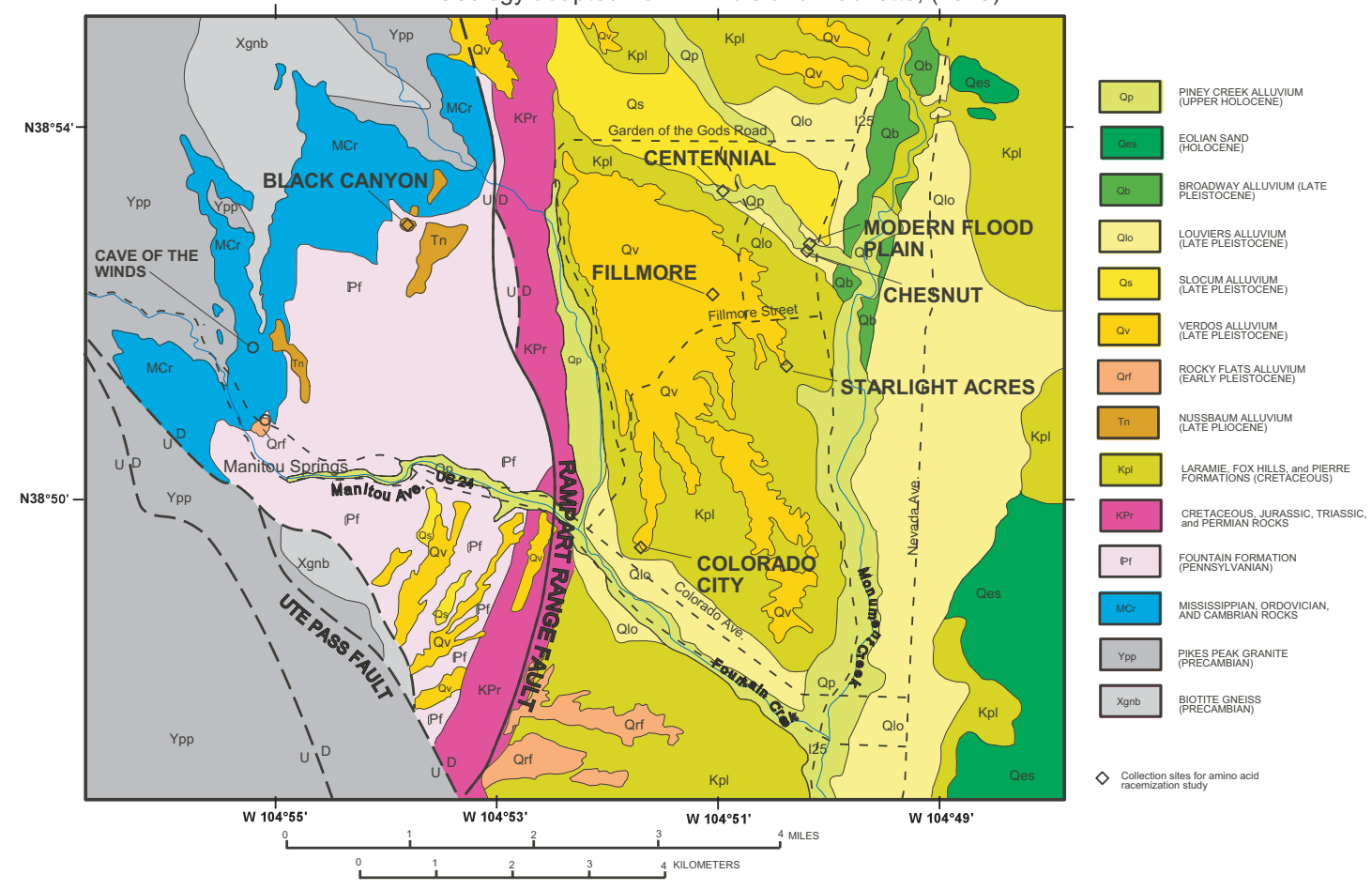

(generally $\sim 5.0 \mathrm{~cm}$ ). The samples at Sniders Hall, Mummys Alcove, and Hole 1 were taken with $3.2 \mathrm{~cm}^{3}$ sampling cubes; all other samples were taken with $13.5 \mathrm{~cm}^{3}$ cubes.

In the lab, the NRM (Natural Remanent Magnetization) of all samples was initially measured. Subsequently, the samples were subjected to alternating-field (A. F.) demagnetization and remeasured. All samples were first demagnetized at 10 , and then at 15 millitesla (mT). Some samples at the bottom of Hole 5 that displayed aberrant inclinations and declinations were additionally demagnetized at fields up to $30 \mathrm{mT}$. All remanence measurements were made on a Schonstedt SSM 1A spinner magnetometer with a sensitivity of $1 \mathrm{X} 10^{-4} \mathrm{~A} / \mathrm{m}$. Repeat measurements indicate an angular reproducibility of $\sim 2^{\circ}$ at an intensity of $1 \mathrm{X} 10-6 \mathrm{~A} / \mathrm{m}^{2}$.

\section{Age Of Cave Passages}

Because Cave of the Winds is an erosional feature, its exact age cannot be determined. However, geologic and geomorphic features related to the cave can be used to bracket the age of incipient and major cave development. Solution breccia in the Manitou Formation indicate that there may have been some Middle Ordovician to Devonian cave development (Forster, 1977). Sediment-filled paleo-caves and paleo-sinkholes at Cave of the Winds in- dicate Devonian to Late Mississippian karst development (Hose \& Esch, 1992). Subsequent Cenozoic dissolution along some of these paleokarst features has resulted in the formation of cave passage (Fish, 1988). Between the Pennsylvanian and Late Cretaceous, about $3000 \mathrm{~m}$ of sediments, which contain abundant shale beds, were deposited over the initial cave. Very little, if any, cave development could take place during this period of deep burial under the thick blanket of the nearly impervious rock.

The Laramide Orogeny, beginning in the Late Cretaceous ( $75 \mathrm{Ma}$, Mutschler et al., 1987), was associated with the uplift of the Rocky Mountains. The uplift, which included the Rampart Range and Pikes Peak, caused the activation of the Ute Pass and Rampart Range Faults (Morgan, 1950; Bianchi, 1967). In the Manitou Springs area, movement on the Ute Pass Fault resulted in the folding, jointing and minor faulting of the rocks (Hamil, 1965; Blanton, 1973). The subsequent flow of corrosive water along the fractures related to the folding and faulting would produce most of the passages in Cave of the Winds and nearby caves. Uplift during the early Laramide Orogeny increased the topographic relief in the Manitou Springs area, resulting in the initiation of erosion of the overlying sediments and also increased 
Figure 3. Map Of Cave Of The Winds, Manitou Springs, Colorado showing locations of samplings sites.

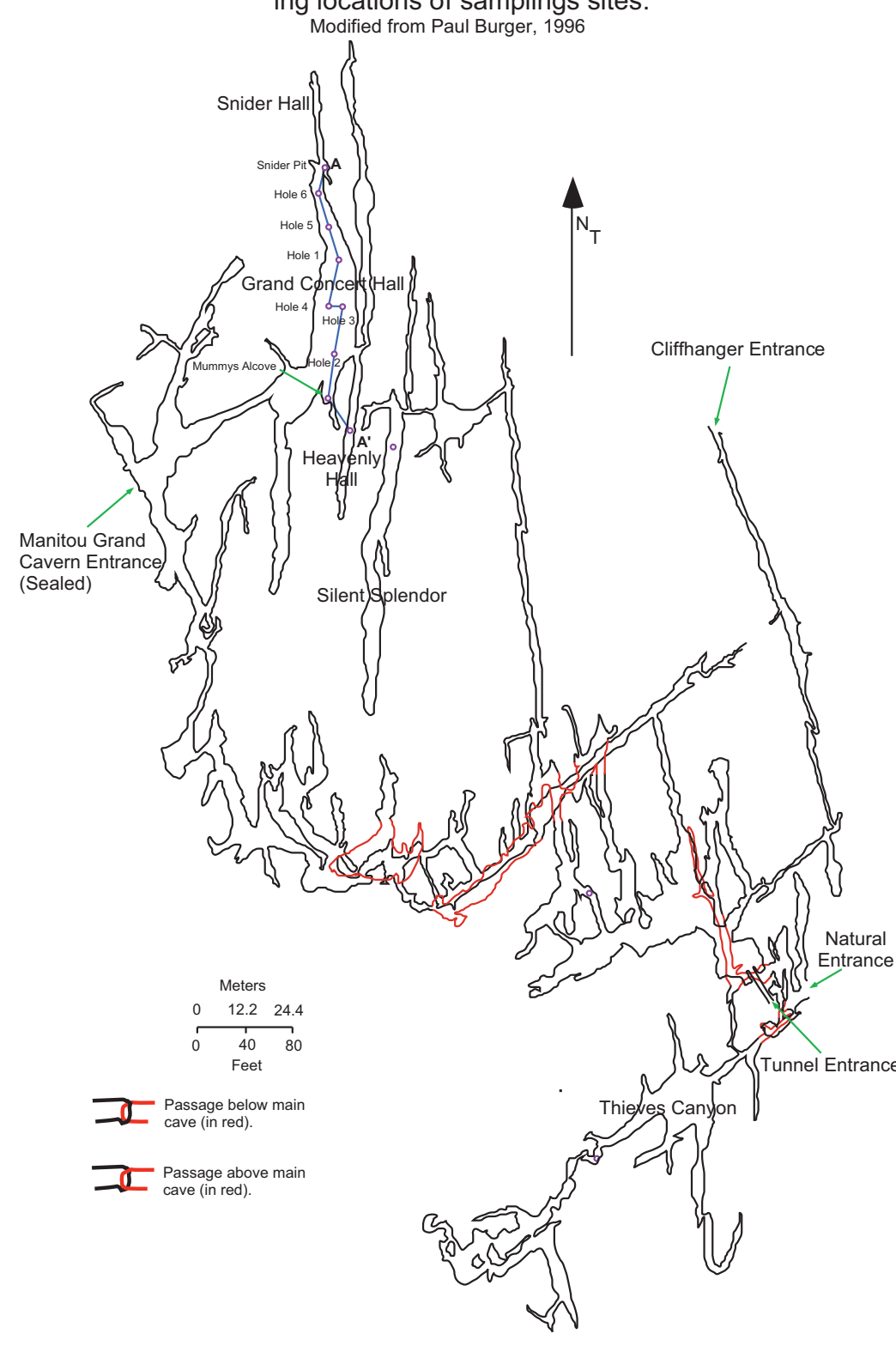

A Late Miocene-Early Pliocene alluvial deposit on the Rampart Range, $18 \mathrm{~km}$ northwest of Manitou Springs, indicates renewed MiocenePliocene uplift, which in some places was up to $3000 \mathrm{~m}$ (Epis and Chapin, 1975). At the same time, movement along the Ute Pass Fault caused redirection of Fountain Creek from its former position near the abovementioned alluvial deposit to its present position (Scott, 1975). Valley entrenchment along the Ute Pass Fault by Fountain Creek, in conjunction with uplift, created the hydraulic head needed to drive the mineral springs, the mixing zone, and limestone dissolution (Luiszer, 1997). It is likely, therefore, that the age for the onset of major dissolution at Cave of the Winds is probably Late Miocene-Early Pliocene (7 Ma to $4 \mathrm{Ma}$ ).

\section{Age Of Cave Fill}

Sedimentation in the cave appears to have been contemporaneous with passage development. There are a few problems in proving this chronology. One is the lack of datable materials in the sediments, such as fossils or volcanic ashes. Preliminary study of the sediments indicated that magnetic reversal stratigraphy (magnetostratigraphy) might be useful in dating the sediments. The use of this method, however, presents another problem: it requires that the polarity sequence be constrained by at least one independent date.

The Nussbaum Alluvium, which

the local hydraulic head. The erosion of some of the impervious shale along with the increased hydraulic head may have initiated some minor water flow through the joints and faults, causing incipient dissolution. However, in the first $25 \mathrm{~m}$. y. of the Laramide Orogeny, erosional stripping almost equaled uplift (Tweto, 1975) resulting in a subdued topography with a maximum elevation of about $1000 \mathrm{~m}$ (Epis and Chapin, 1975). It was unlikely, therefore, that a large hydraulic head existed--a necessary hydraulic head that would have had to be present to force through the rock the large volumes of water needed for development of a large cave system. crops out east of the cave and is $\sim 20 \mathrm{~m}$ higher in elevation, is apparently related to coarse sediments present at the top of sediment sequences in Cave of the Winds. If an age can be assigned to the Nussbaum Alluvium and the relationship of the Nussbaum Alluvium to the coarse sediments in the cave deciphered, then an independent date can be assigned to at least one polarity reversal in the cave. The age of the Nussbaum Alluvium will be dealt with first, because the age of the Nussbaum Alluvium is poorly constrained. Various authors have assigned that range from Late Pliocene to early Pleistocene (Scott, 1963; Soister, 1967; Scott, 1975). For the purpose of correlating the Nussbaum Allu- 
vium with a paleomagnetic reversal, a more accurate date of the Nussbaum Alluvium was needed. This problem was solved by aminostratigraphy.

\section{Aminostratigraphy}

Most amino acids exist as two forms: L- and D-isomers (Miller \& Brigham-Grette, 1989). In a living organism, the amino acids are L-isomers. After the death of an organism, the amino acids racemize, which is the natural conversion of the L-isomers into D-isomers. Eventually the amino acids in the dead organism equilibrate to a 50/50 mixture of $\mathrm{L}$ - and D-isomers. The amino acids used in the present study are D-alloisoleucine and Lisoleucine $(\mathrm{A} / \mathrm{I})$. These amino acids are somewhat more complex, because L-isoleucine actually changes to a different molecule, D-alloisoleucine. This reaction, similar to racemization, is called epimerization (Miller and Brigham-Grette, 1989).

The rate at which this reaction takes place is a function of temperature. For example, if the burial-temperature history for a group of mollusks of different ages has been the same, the ratio of the two amino acids - alloisoleucine and isoleucine $(\mathrm{A} / \mathrm{I})$ - in the mollusk shells can be used for relative dating and in some cases, absolute dating (Miller and Brigham-Grette, 1989). Because temperature controls the rate of racemization, the temperature history of buried fossils must be considered before using A/I to derive ages.

Solar insolation, fire, altitude, and climate can effect the burial temperature of fossils. Diurnal or seasonal solar heating of fossils buried at shallow depths may accelerate racemization and increase the apparent age of the samples (Goodfriend, 1987; Miller and Brigham-Grette, 1989). Therefore, samples should be obtained from depths that exceed $2 \mathrm{~m}$ (Miller and Brigham-Grette, 1989). During the intense heat associated with a fire, racemization can also be greatly accelerated. For example, charcoal, which has a ${ }^{14} \mathrm{C}$ age of $\sim 1500$ years, found with snails at Manitou Cave suggests that the snails were exposed to a forest fire before being transported into the cave. If so, the A/I of the snails may be anomalously high for their age.

The altitude of the collection site can also affect racemization rates. For example, snails in this study were collected at altitudes between 1890 and $2195 \mathrm{~m}$ above sea level. Because of the normal adiabatic effect, the highest site averages about $1.7^{\circ} \mathrm{C}$ less than the lowest site. Another temperature variable is long-term climate change. For example, the Nussbaum Alluvium has probably been exposed to episodes of higher or lower temperatures for much longer periods of time than the younger alluvia. Because post-depositional thermal histories are impossible to ascertain, the burial temperature for all alluvia in this study are assumed to be the same.

\section{Mollusks Results}

In all, over 10,000 mollusks, which included one species of slug, one species of clam, and 24 species of snail, were identified and counted. The tabulated number for each species is the number of shells that could be identified. For example, the Louviers site had $\sim 3,000$ snails that could not be identified because they were too small (juvenile) or broke. Because of the small weight of the individual snails $(0.3$ to $5.0 \mathrm{mg}$ ) in relation to the $30 \mathrm{mg}$ necessary for testing, only abundant species that occurred at multiple sites could be used for the amino-acid study. The species chosen for the Nussbaum (Black Canyon) were Vallonia cyclophorella and Pupilla muscorum and from the Verdos, Vallonia cyclophorella and Gastrocopta armifera (Table 1). All of the alloisoleucine and isoleucine $(\mathrm{A} / \mathrm{I})$ ratios of the snails along with laboratory identification numbers are tabulated in Table 2A. Table $2 \mathrm{~B}$ contains the average and standard deviation of the A/I of selected snails from each site.

\section{Discussion Of A-I Ratios}

The epimerization rates of the four species used in this study are very similar. This is indicated in Table $2 \mathrm{~A}$ by the comparable A/I values of different snail species at the same sample location. Moreover, shell size did not appear to greatly affect the A/I. For example, the average Gastrocopta armifera shell weighs $5 \mathrm{mg}$; the Vallonia cyclophorella $1 \mathrm{mg}$; yet, the A/I for these shells from Manitou Cave are similar (Table 2A).

The snails from the Verdos Alluvium, which include the Starlight, Fillmore, and Colorado City sites (Locations on Fig. 2), were used to test the A/I reproducibility of samples from one site and to compare the A/I from the different sites. Extra effort was put into assuring that the amino acid ratios of snails from Verdos Alluvium were as accurate as possible, because any errors in their A/I determination would greatly amplify the inaccuracies of the extrapolated age of the Nussbaum Alluvium (Fig. 4). Therefore, the Starlight site was sampled three times and the Fillmore site, twice. Although each of the two sub-sites at Colorado City were sampled twice, the scarcity of Vallonia cyclophorella and Gastrocopta armifera necessitated combining all snail shells of similar species from the entire site and from both sampling trips. One Starlight-site sample (Table 2A, Lab \# AAL-5768) was excluded from the final curve fitting because it had an anomalously high ratio as compared to the others from that site. The snails that made up this sample (AAL-5768) may have been from an older reworked alluvium or there may have been a problem with their preparation or analysis.

The data from the Colorado City site were also excluded from the final curve fitting, primarily because the A/I of the two species were very different from each other 


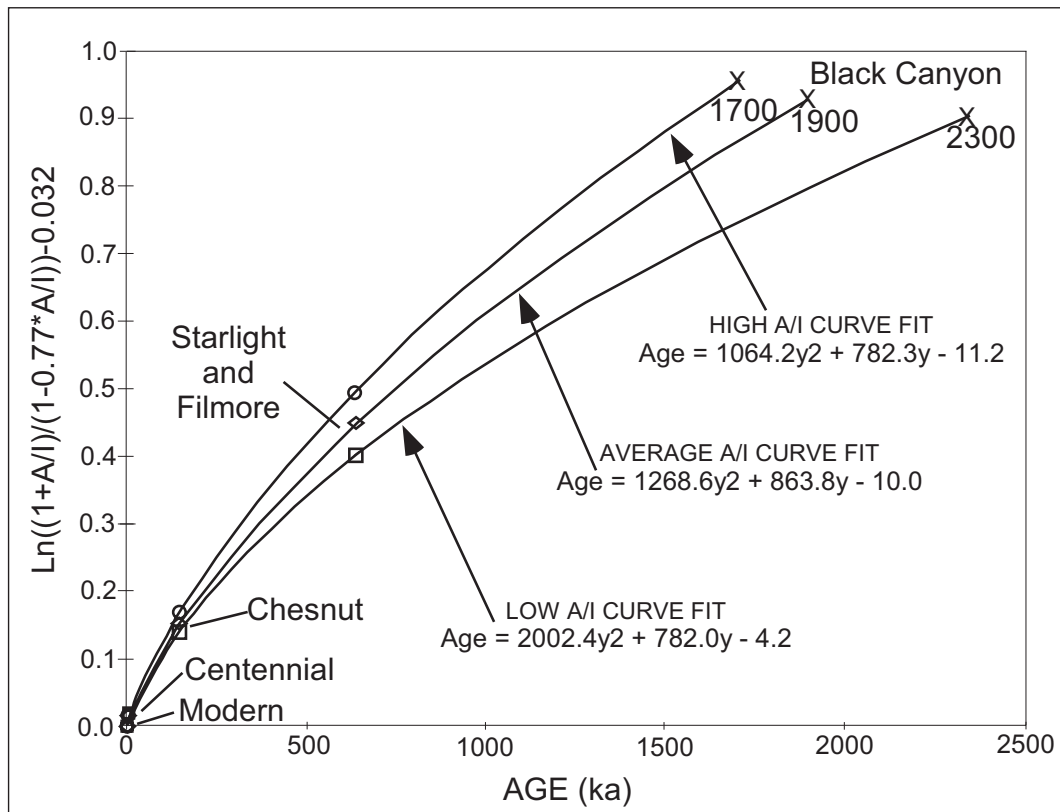

Figure 4. The A/I of snails from the Starlight and Filmore (Verdos Alluvium), Chesnut (Louviers Alluvium), Centennial (Piney Creek), and Modern Flood Plain sites are used for curve fitting. The diamonds represent the curve fit of the average $A / I$. The circles and squares represent the curve fits of $+/-$ one standard deviation of the A/I. The A/I of the snails from the Black Canyon site with the appropriate equations are used to extrapolate the age of the Nussbaum Alluvium (1.9+0.4/-0.2 Ma).

The live snails were not analyzed because the flesh, which may have different amino-acid ratios than the shells, might have contaminated the shell A/I ratios. Empty shells were used for analysis and assumed to be about one year old. There is a possibility that the modern shells were reworked from older sediments such as the Piney Creek Alluvium. However, the abundant live snails mixed with the dead snails of the same species suggests that all snail specimens were contemporaneous.

The Piney Creek Alluvium site (Fig. 2) has been mapped as Piney Creek and Post-Piney Creek (Trimble and Machette, 1979). Charcoal collected from the Piney Creek site (location on Fig. 2) was ${ }^{14} \mathrm{C}$ dated at $1542 \pm 130$ years old (Table 3 ) indicating that the site should be mapped as Post-Piney Creek Alluvium. The snails collected at Manitou Cave, which have relatively high A/I ratios, were initially thought to be about the same age as dated deposits

and both A/I were much lower than those from the Starlight and Fillmore sites. Their low A/I would indicate that the Colorado City site may actually be either the Slocum or Louviers Alluvium. The anomalously low ratios, of course, could also be the result of contamination from modern shells or organic material.

Determination of anomalously high or low ratios would be impossible without multiple sampling. Taking one sample per site would have been useless for this study. Two samples per site was acceptable when the A/I ratios were about the same for both species. With 12 samples from the Verdos Alluvium, it was quite appropriate to discard the highest and lowest ratios.

\section{Age Of The Alluvia}

The higher A/I of the snails from Black Canyon site, which is mapped as Nussbaum Alluvium, indicates that it is older than the other alluvia (Table 2A). Furthermore, by ascertaining the ages of the younger alluvia, plotting those against their relative $\mathrm{A} / \mathrm{I}$ ratio, and fitting a curve to the resultant plot, a equation can be derived that can be used to calculate the approximate age of the Nussbaum Alluvium.

Snails from the modern flood plain (Fig. 2) were used to ascertain the A/I ratio of modern snails. About $50 \%$ of the snails at this site were alive when collected. at Narrows Cave. Narrows Cave is located $\sim 0.4 \mathrm{~km}$ north of Manitou Cave contains flood deposits intercalated with flowstone that has been dated and found to have a maximum uranium-thorium age of $32 \pm 2 \mathrm{Ka}$ (Table 3 ). They were thought to be the same age because the snails at Manitou Cave and the deposits at were both deposited by paleo-floods and both had similar heights above Williams Canyon Creek. However, charcoal associated with the snails in Manitou Cave was ${ }^{14} \mathrm{C}$ dated with an age of $1552 \pm 75$ years (Table 3 ). Apparently, either young charcoal mixed with old snails during the paleo-flood or the snails were affected by a forest fire that induced anomalously high A/I ratios. This conflicting evidence made it necessary to exclude the Manitou Cave data from the curve fitting.

The Louviers Alluvium site was mapped by Trimble and Machette (1979). Elsewhere in Colorado the Louviers has been dated at $115 \mathrm{Ka}$ by Machette (1975). Szabo (1980) gave a minimum age of $102 \mathrm{Ka}$ and inferred that the maximum age was $\sim 150 \mathrm{Ka}$. The Fillmore, Colorado City, and Starlight sites are all mapped as Verdos Alluvium (Trimble and Machette, 1979), which, in the Denver area, contains the 640-Ka Lava Creek B ash near its base (Sawyer et. al., 1995; Izett et. al., 1989; Machette, 1975). Because the Lava Creek B ash gives the maximum age for the Verdos Alluvium, 
Tab. 1: Species identified, their location, and amount of shells counted.

\begin{tabular}{|c|c|c|c|c|c|c|c|c|c|c|c|c|c|c|c|c|c|c|}
\hline \multirow{3}{*}{\begin{tabular}{|l} 
\\
$\begin{array}{l}\text { Carychium exiguum } \\
\text { (Say) }\end{array}$
\end{tabular}} & \multirow{2}{*}{\multicolumn{2}{|c|}{$\begin{array}{l}\text { Modern } \\
\text { Flood } \\
\text { Plain }\end{array}$}} & \multirow{2}{*}{\multicolumn{2}{|c|}{ Centennial }} & \multirow{2}{*}{\multicolumn{2}{|c|}{$\begin{array}{l}\text { Manitou } \\
\text { Cave }\end{array}$}} & \multirow{2}{*}{\multicolumn{2}{|c|}{ Chesnut }} & \multirow{2}{*}{\multicolumn{2}{|c|}{$\begin{array}{l}\text { Filmore } \\
\text { (Verdos) }\end{array}$}} & \multirow{2}{*}{\multicolumn{2}{|c|}{$\begin{array}{l}\text { Starlight } \\
\text { (Verdos) }\end{array}$}} & \multicolumn{4}{|c|}{ Colorado City } & \multirow{2}{*}{\multicolumn{2}{|c|}{$\begin{array}{c}\text { Black } \\
\text { Canyon } \\
\text { (Nussbaum) }\end{array}$}} \\
\hline & & & & & & & & & & & & & \multicolumn{2}{|c|}{$\begin{array}{l}\text { East } \\
\text { (Verdos) }\end{array}$} & \multicolumn{2}{|c|}{$\begin{array}{c}\text { West } \\
\text { (Verdos) }\end{array}$} & & \\
\hline & & & & & & & & & & & 8 & 3 & 105 & 35 & 18 & 5 & & \\
\hline $\begin{array}{l}\text { Cionella lubrica } \\
\text { (Muller) }\end{array}$ & & & & & 20 & 3 & 1 & 0 & & & 2 & 1 & & & & & & \\
\hline $\begin{array}{l}\text { Columella alticola } \\
\text { (ingersoll) }\end{array}$ & & & & & & & 4 & 0 & & & & & 1 & 0 & & & & \\
\hline Derocerus spp. & & & & & & & & & & & 1 & 0 & & & 4 & 1 & & \\
\hline Discus whitneyi & & & & & 4 & 1 & 4 & 0 & & & & & & & & & & \\
\hline $\begin{array}{l}\text { Euconulus fulvus } \\
\text { (Muller) }\end{array}$ & & & & & 16 & 2 & 20 & 2 & & & & & 2 & 1 & & & & \\
\hline Fossaria parva (Lea) & & & & & & & 19 & 2 & & & 3 & 1 & 8 & 3 & 10 & 3 & & \\
\hline $\begin{array}{l}\text { Gastrocopta } \\
\text { armifera (Say) }\end{array}$ & 1 & 0 & 1 & 0 & 47 & 7 & 5 & 1 & 38 & 7 & 17 & 7 & 5 & 2 & & & & \\
\hline $\begin{array}{l}\text { Gastrocopta cristata } \\
\text { Pilsbry }\end{array}$ & 1 & 0 & & & & & & & 1 & 0 & 15 & 6 & 19 & 6 & 10 & 3 & & \\
\hline $\begin{array}{l}\text { Gastrocopta } \\
\text { holzingeri (Sterki) }\end{array}$ & 6 & 2 & & & & & 6 & 1 & & & 96 & 39 & 37 & 12 & 3 & 1 & & \\
\hline $\begin{array}{l}\text { Gastrocopta } \\
\text { pellucida (Pfeiffer) }\end{array}$ & 1 & 0 & & & 193 & 27 & & & 3 & 1 & & & 6 & 2 & 3 & 1 & 136 & 28 \\
\hline $\begin{array}{l}\text { Gastrocopta } \\
\text { procera (Gould) }\end{array}$ & 6 & 2 & & & 5 & 1 & & & 35 & 6 & 5 & 2 & 14 & 5 & 3 & 1 & & \\
\hline $\begin{array}{l}\text { Gyraulus parvus } \\
\text { (Say) }\end{array}$ & & & & & & & & & & & & & 2 & 1 & 53 & 13 & & \\
\hline $\begin{array}{l}\text { Hawaiia minuscula } \\
\text { (Binney) }\end{array}$ & 23 & 6 & 43 & 5 & 82 & 12 & 134 & 14 & 84 & 14 & 12 & 5 & 20 & 7 & 12 & 3 & 26 & 5 \\
\hline Oreohelix spp. & & & & & 28 & 4 & & & & & & & & & & & & \\
\hline Oxyloma spp. & & & & & & & 20 & 2 & & & 6 & 2 & 5 & 2 & & & & \\
\hline Physa spp. & & & & & & & & & & & & & 1 & 0 & 10 & 3 & & \\
\hline $\begin{array}{l}\text { Pisidium } \\
\text { casertanum (Poli) }\end{array}$ & & & & & & & & & & & & & 13 & 4 & 200 & 50 & & \\
\hline $\begin{array}{l}\text { Pupilla muscorum } \\
\text { (Linne) }\end{array}$ & 70 & 18 & 174 & 22 & 20 & 3 & 4 & 0 & 2 & 0 & 9 & 4 & 12 & 4 & 2 & 1 & 52 & 11 \\
\hline $\begin{array}{l}\text { Pupoides albilabris } \\
\text { (C.B. Adams) }\end{array}$ & & & & & & & & & 7 & 1 & 4 & 2 & 8 & 3 & & & & \\
\hline $\begin{array}{l}\text { Pupoides } \\
\text { hordaceous (Gabb) }\end{array}$ & & & & & & & & & & & & & & & & & 133 & 28 \\
\hline $\begin{array}{l}\text { Pupoides inornata } \\
\text { Vanatta }\end{array}$ & 35 & 9 & 7 & 1 & 1 & 0 & & & 130 & 22 & 3 & 1 & 6 & 2 & 9 & 2 & 7 & 1 \\
\hline Stagnicola spp. & & & & & & & & & & & & & & & 10 & 3 & & \\
\hline Succinea spp. & & & 4 & 1 & & & & & 45 & 8 & & & & & 3 & 1 & & \\
\hline $\begin{array}{l}\text { Vallonia } \\
\text { cyclophorella } \\
\text { (Sterki) }\end{array}$ & 250 & 64 & 579 & 72 & 197 & 28 & 381 & 39 & 240 & 41 & 60 & 24 & 20 & 7 & 32 & 8 & 123 & 26 \\
\hline $\begin{array}{l}\text { Vertigo gouldi and } \\
\text { ovata }\end{array}$ & & & 1 & 0 & 4 & 1 & 390 & 39 & & & & & & & & & & \\
\hline $\begin{array}{l}\text { Zonitoides arboreus } \\
\text { (Say) }\end{array}$ & 1 & 0 & & & 96 & 14 & 1 & 0 & & & 7 & 3 & 20 & 7 & 15 & 4 & 6 & 1 \\
\hline \multirow[t]{2}{*}{ TOTAL } & 394 & 100 & 809 & 100 & 713 & 100 & 989 & 100 & 585 & 100 & 248 & 100 & 304 & 100 & 397 & 100 & 483 & 100 \\
\hline & $\#$ & $\%$ & \# & $\%$ & \# & $\%$ & $\#$ & $\%$ & $\#$ & $\%$ & $\#$ & $\%$ & $\#$ & $\%$ & $\#$ & $\%$ & $\#$ & $\%$ \\
\hline
\end{tabular}


Tab. 2A: Alloisoleucine and isoleucine (A/I) ratios of snails.

\begin{tabular}{|c|c|c|c|c|c|c|c|}
\hline \multirow{2}{*}{$\begin{array}{l}\text { Sample Location } \\
\text { Modern }\end{array}$} & \multirow{2}{*}{$\frac{\text { Species }}{\text { P }}$} & \multirow{2}{*}{$\begin{array}{l}\text { Lab Number } \\
\text { AAL-5990 }\end{array}$} & \multicolumn{3}{|c|}{ Results } & \multirow{2}{*}{$\begin{array}{r}\text { Average } \\
0.021\end{array}$} & \multirow{2}{*}{$\begin{array}{r}\begin{array}{r}\text { Standard } \\
\text { Deviation }\end{array} \\
0.001\end{array}$} \\
\hline & & & 0.020 & 0.022 & & & \\
\hline Modern & V & AAL-5989 & 0.021 & 0.020 & & 0.021 & 0.001 \\
\hline Centennial & $\mathrm{P}$ & AAL-5970 & 0.023 & 0.021 & & 0.022 & 0.001 \\
\hline Centennial & V & AAL-5969 & 0.024 & 0.032 & & 0.028 & 0.004 \\
\hline Manitou Cave & G & AAL-5993 & 0.042 & 0.056 & 0.051 & 0.050 & 0.006 \\
\hline Manitou Cave & $P$ & AAL-5992 & 0.039 & 0.044 & 0.041 & 0.041 & 0.002 \\
\hline Manitou Cave & V & AAL-5991 & 0.043 & 0.069 & & 0.056 & 0.013 \\
\hline Chesnut & GO & AAL-5972 & 0.106 & 0.124 & & 0.115 & 0.009 \\
\hline Chesnut & V & AAL-5971 & 0.106 & 0.103 & & 0.105 & 0.002 \\
\hline Colorado City & G & AAL-5986 & 0.154 & 0.210 & 0.163 & 0.176 & 0.025 \\
\hline Colorado City & V & AAL-5985 & 0.076 & 0.083 & & 0.080 & 0.004 \\
\hline Fillmore 1 & $\mathrm{G}$ & AAL-5976 & 0.279 & 0.274 & & 0.277 & 0.003 \\
\hline Fillmore 1 & V & AAL-5975 & 0.298 & 0.275 & & 0.287 & 0.012 \\
\hline Fillmore 2 & G & AAL-5988 & 0.239 & 0.233 & & 0.236 & 0.003 \\
\hline Fillmore 2 & V & AAL-5987 & 0.283 & 0.270 & & 0.277 & 0.007 \\
\hline Starlight & $\mathrm{P}$ & AAL-5768 & 0.423 & 0.414 & 0.420 & 0.419 & 0.004 \\
\hline Starlight & V & AAL-5767 & 0.276 & 0.317 & 0.296 & 0.296 & 0.017 \\
\hline Starlight 1 & $\mathrm{G}$ & AAL-5974 & 0.302 & 0.322 & & 0.312 & 0.010 \\
\hline Starlight 1 & $\mathrm{~V}$ & AAL-5973 & 0.307 & 0.231 & 0.224 & 0.254 & 0.038 \\
\hline Starlight 2 & $\mathrm{G}$ & AAL-5978 & 0.292 & 0.298 & & 0.295 & 0.003 \\
\hline Starlight 2 & V & AAL-5977 & 0.246 & 0.244 & & 0.245 & 0.001 \\
\hline \multirow[t]{2}{*}{ Black Canyon } & $\mathrm{P}$ & AAL-5766 & 0.502 & 0.531 & 0.543 & & \\
\hline & & & & & 0.529 & 0.526 & 0.015 \\
\hline \multirow[t]{2}{*}{ Black Canyon } & V & AAL-5765 & 0.545 & 0.545 & 0.546 & & \\
\hline & & & 0.544 & 0.515 & 0.576 & 0.545 & 0.018 \\
\hline
\end{tabular}

$\mathrm{V}=$ Vallonia cyclophorella $\mathrm{P}=$ Pupilla muscorum $\mathrm{G}=$ Gastrocopta armifera $\mathrm{GO}=$ Vertigo gouldii and Vertigo ovata

the inferred maximum age of $\sim 150 \mathrm{Ka}$ was assigned to the Louviers Alluvium. The interpolated age of the

Tab. 2B: Average values and standard deviation of $A / I$ ratios of selected snails from each site.

\begin{tabular}{|l|l|l|l|}
\hline & $\begin{array}{c}\text { Average } \\
\text {-standard } \\
\text { deviation }\end{array}$ & Average & $\begin{array}{c}\text { Average }+ \\
\text { standard } \\
\text { deviation }\end{array}$ \\
\hline Modern Flood Plain & 0.020 & 0.021 & 0.022 \\
\hline Centennial & 0.021 & 0.025 & 0.029 \\
\hline Chesnut & 0.103 & 0.110 & 0.117 \\
\hline Filmore and Starlight & 0.249 & 0.275 & 0.301 \\
\hline Black Canyon & 0.523 & 0.536 & 0.549 \\
\hline
\end{tabular}

Nussbaum Alluvium, therefore, represents its maximum age.

\section{Parabolic Curve Fitting}

Ages and A/I data (Table 2B ) from four of the younger alluvia, together with A/I data from the Nussbaum, were used to extrapolate the age of the Nussbaum. Various authors have applied linear and parabolic curve fitting to amino acid data for both interpolation and extrapolation of age (Miller \& Brigham-Grette, 1989). Mitterer \& Kriausakul (1989) have employed the parabolic function $\left(y=x^{2}\right)$ with good results. Applying the generalized parabolic equation $\left(\mathrm{y}=\mathrm{A}+\mathrm{Bx}+\mathrm{Cx}^{2}\right)$ to my data resulted in a better curve fit than the specialized parabolic function $\left(y=x^{2}\right)$. Use of the specialized parabolic function assumes that the $\mathrm{A} / \mathrm{I}$ ratio starts at 0.0 and that at an initial age near zero, the racemization rate is infinitely large. The data from my study area suggest that both of these assumptions are invalid (Table 2B and Fig. 4).

Ignoring the $\mathrm{A}+\mathrm{Bx}$ terms appears to have little effect on curve fitting of relatively young snails $(<100 \mathrm{Ka})$. The generalized parabolic function, however, was used in this study because the age of the Nussbaum Alluvium is extrapolated 3 to 4 times beyond the oldest calibration point. Parabolic-curve fits for the average ratio with error bars of one standard deviation indicate an extrapolated age for the Nussbaum Alluvium of 1.9 $+0.4 /-0.2 \mathrm{Ma}$ (Fig. 4).

Tab. 3: Uranium-thorium and ${ }^{14} \mathrm{C}$ dates.

\begin{tabular}{|l|c|c|}
\hline & ${ }^{14}$ C Age (years B.P.) & Lab. Number* \\
\hline Centennial site & $1495 \pm 130$ & GX-15992 \\
\hline Manitou Cave & $1505 \pm 75$ & GX-15993 \\
\hline *Krueger Enterprises Inc. \\
\hline \multicolumn{3}{|c|}{ Uranium-thorium Age** (years B.P.) } \\
\hline Narrows Cave & $32,000 \pm 2,000$ \\
\hline${ }^{* *}$ Dan Muhs, U.S.G.S., 1990, per. comm. \\
\hline
\end{tabular}


Extrapolating a date that is 3 to 4 times more than the maximum calibration date is a practice generally frowned up. I believe that by carefully collecting and handling samples, obtaining precise analysis of the amino acids, acquiring the best age determinations of the younger deposits, and curve fitting with the generalized parabolic function, I have ameliorated problems usually associated with such extrapolation. The 1.9-Ma date for the Nussbaum Alluvium is appropriate only for the unit mapped in the Manitou Springs area; it may not be correlative with the type section in Pueblo, Colorado. The date, $1.9+0.4 /-0.2 \mathrm{Ma}$, which is the most accurate date available for the Nussbaum Alluvium, was used to calibrate the magnetostratigraphy of the sediments in Cave of the Winds.

\section{Magnetostratigraphy}

Rocks and unconsolidated sediments can be magnetized by the magnetic field of the earth (Tarling 1983), acquiring natural remanent magnetization (NRM). A type of NRM in sediments is detrital remanent magnetization (DRM), which is formed when the magnetic grains of a sediment, such as magnetite or hematite, are aligned with the earth's magnetic field during or soon after deposition (Verosub, 1977). The DRM of a sediment has the same orientation as and its intensity is proportional to, the earth's magnetic field (Verosub, 1977).

The magnetic field of the earth has reversed many times in the past (Tarling, 1983). Polarity time scales have been constructed by compiling the reversals and the radiometrically derived dates of the rock in which the reversals are preserved, (Mankinen \& Dalrymple, 1979; Harland et. al., 1982; Hailwood, 1989; Cande and Kent, 1992).

There are several ways to use this time scale to date sediments. By assuming that the top of a sediment section starts at the present and sedimentation has been uninterrupted, such as in deep ocean basins, it is a simple matter of counting the reversals and correlating them with the polarity time scale. Because of erosion or a hiatus in deposition, however, the top of many sediment sections will have an older age that must be ascertained by some other technique before reversals in the section can be correlated with the polarity time scale.

Another way of dating sediments is by pattern matching. If the sedimentation rate of an undated section is constant or known and there are many reversals (5-10), the polarity record can be matched to the pattern of the polarity time scale to provide dating. This is possible because the timing of reversals is apparently random (Tarling, 1983). Therefore, the timing of a sequence of reversals is seldom repeated. Both of these techniques mentioned here were used to refine the age of the sediments at Cave of the Winds.

\section{Paleomagnetic Results}

All the paleomagnetic data from Hole 6 are presented to give an example of all the raw data from all sampling sites and how the samples responded to demagnetization ( $\mathrm{Ta}$ ble 4). Inspection of the complete data set revealed that all samples responded very similarly to demagnetization. The complete data set of sites included in this study as well as other miscellaneous sites not used in this study are available from the author on computer storage disks. Sample depth and magnetic declination after 15-mT AF demagnetization from each site were used to correlate the magnetic polarity within and between the Grand Concert Hall and nearby Heavenly Hall (Fig. 5). An exception to use of the 15-mT-AF demagnetization is Hole 5 , where samples from 6.5 to $10.0 \mathrm{~m}$ were subjected to 20-, 25-, and 30-mT-AF demagnetization. The higher fields were applied in an attempt to remove secondary overprints. Even with the increasing demagnetization,

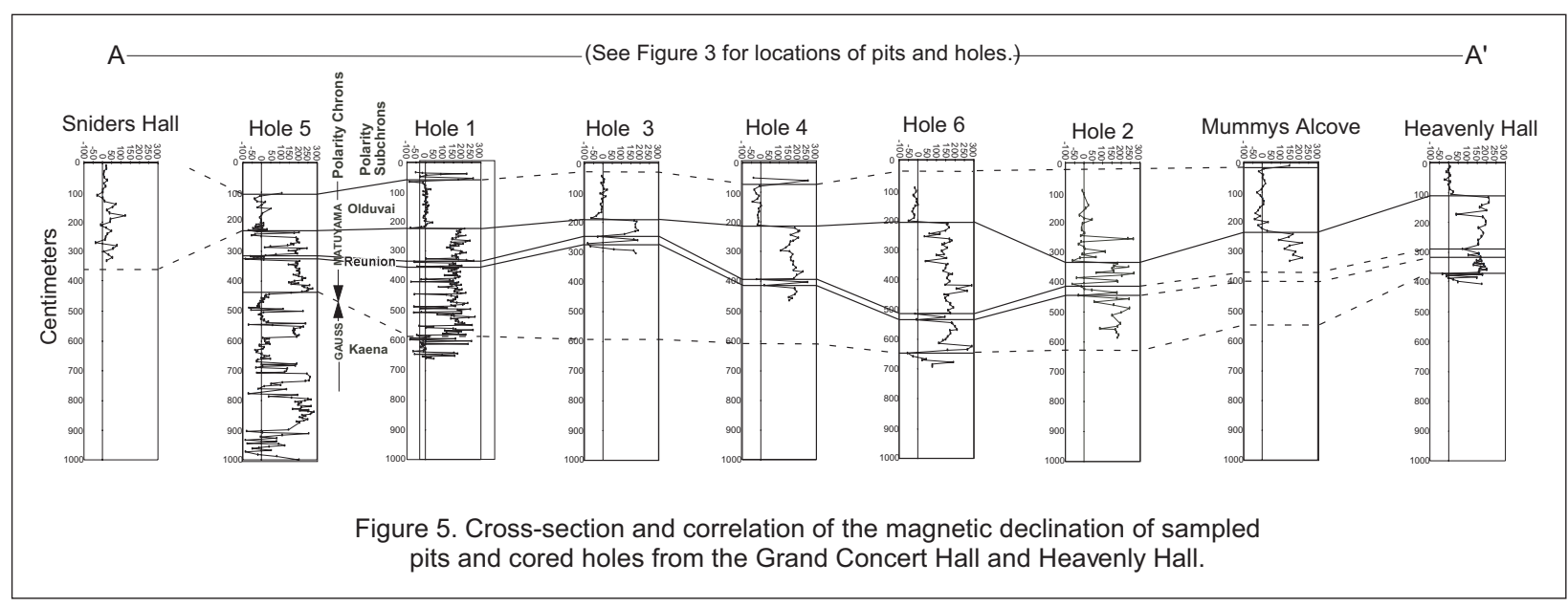


Tab. 4: Complete Paleomagnetic results of Hole 6, Grand Concert Hall

\begin{tabular}{|c|c|c|c|c|c|c|c|c|c|c|}
\hline \multirow{2}{*}{$\begin{array}{l}\text { Sample } \\
\text { Number }\end{array}$} & \multirow{2}{*}{$\begin{array}{r}\text { Depth } \\
\mathrm{cm}\end{array}$} & \multicolumn{3}{|c|}{ Natural } & \multicolumn{3}{|c|}{$10 \mathrm{mT}$} & \multicolumn{3}{|c|}{$15 \mathrm{mT}$} \\
\hline & & Dec. & Inc. & Int. & Dec. & Inc. & Int. & Dec. & Inc. & Int. \\
\hline 11 & 80 & -10 & 62 & $1.2 \mathrm{E}-4$ & -21 & 55 & $5.4 \mathrm{E}-5$ & -14 & 58 & 4.7E-5 \\
\hline 12 & 93 & -30 & 45 & $1.5 \mathrm{E}-4$ & -7 & 54 & $6.8 \mathrm{E}-5$ & -16 & 52 & $5.0 \mathrm{E}-5$ \\
\hline 13 & 105 & -11 & 52 & $2.0 \mathrm{E}-4$ & -4 & 52 & $1.2 \mathrm{E}-4$ & -9 & 60 & $1.1 \mathrm{E}-4$ \\
\hline 14 & 118 & -23 & 27 & $1.5 \mathrm{E}-4$ & -23 & 26 & $1.1 \mathrm{E}-4$ & -24 & 24 & $9.7 \mathrm{E}-5$ \\
\hline 21 & 121 & -14 & 44 & $1.8 \mathrm{E}-4$ & -21 & 40 & $1.2 \mathrm{E}-4$ & -20 & 39 & $9.6 \mathrm{E}-5$ \\
\hline 22 & 131 & -11 & 46 & 2.7E-4 & -7 & 39 & $1.7 \mathrm{E}-4$ & -6 & 40 & $1.5 \mathrm{E}-4$ \\
\hline 23 & 141 & -0 & 41 & $1.4 \mathrm{E}-4$ & -13 & 34 & $7.2 \mathrm{E}-5$ & -7 & 37 & $6.6 \mathrm{E}-5$ \\
\hline 24 & 151 & 4 & 42 & $3.2 \mathrm{E}-4$ & 3 & 38 & $2.1 \mathrm{E}-4$ & 2 & 38 & $1.8 \mathrm{E}-4$ \\
\hline 31 & 154 & -11 & 40 & $3.8 \mathrm{E}-4$ & -15 & 32 & $2.1 \mathrm{E}-4$ & -14 & 34 & $1.9 \mathrm{E}-4$ \\
\hline 32 & 163 & -27 & 40 & $2.2 \mathrm{E}-4$ & -21 & 38 & $1.4 \mathrm{E}-4$ & -24 & 36 & $1.3 \mathrm{E}-4$ \\
\hline 33 & 172 & -24 & 41 & $2.6 \mathrm{E}-4$ & -29 & 36 & $1.8 \mathrm{E}-4$ & -30 & 35 & $1.6 \mathrm{E}-4$ \\
\hline 34 & 182 & -17 & 40 & $2.5 \mathrm{E}-4$ & -19 & 38 & $1.7 \mathrm{E}-4$ & -20 & 37 & $1.6 \mathrm{E}-4$ \\
\hline 41 & 184 & -18 & 38 & $4.4 \mathrm{E}-4$ & -18 & 40 & $3.1 \mathrm{E}-4$ & -18 & 39 & $2.9 \mathrm{E}-4$ \\
\hline 42 & 194 & -15 & 41 & $1.8 \mathrm{E}-4$ & -24 & 42 & $1.1 \mathrm{E}-4$ & -20 & 36 & $9.6 \mathrm{E}-5$ \\
\hline 43 & 204 & -17 & 58 & $1.4 \mathrm{E}-4$ & -45 & 62 & 4.7E-5 & -50 & 64 & $3.4 \mathrm{E}-5$ \\
\hline 44 & 213 & 165 & -32 & $1.1 \mathrm{E}-4$ & 162 & -28 & $9.9 \mathrm{E}-5$ & 162 & -29 & $9.1 \mathrm{E}-5$ \\
\hline 51 & 216 & 115 & 11 & $7.0 \mathrm{E}-5$ & 149 & -9 & $6.1 \mathrm{E}-5$ & 156 & -11 & 5.7E-5 \\
\hline 52 & 226 & 155 & -29 & $9.5 \mathrm{E}-5$ & 165 & -36 & $1.0 \mathrm{E}-4$ & 168 & -35 & $9.2 \mathrm{E}-5$ \\
\hline 53 & 236 & -14 & 52 & $7.4 \mathrm{E}-5$ & 144 & 75 & $1.4 \mathrm{E}-5$ & 149 & 59 & $1.1 \mathrm{E}-5$ \\
\hline 54 & 246 & 30 & 50 & $1.3 \mathrm{E}-4$ & 54 & 30 & $5.5 \mathrm{E}-5$ & 62 & 30 & $5.0 \mathrm{E}-5$ \\
\hline 61 & 249 & 81 & 47 & 6.7E-5 & 114 & 14 & $4.6 \mathrm{E}-5$ & 119 & 3 & 3.7E-5 \\
\hline 62 & 257 & -2 & 51 & $1.2 \mathrm{E}-4$ & 34 & 41 & $2.3 \mathrm{E}-5$ & 36 & 16 & $1.0 \mathrm{E}-5$ \\
\hline 63 & 264 & 176 & 58 & $2.7 \mathrm{E}-5$ & 164 & -7 & $2.3 \mathrm{E}-5$ & 170 & -16 & $2.3 \mathrm{E}-5$ \\
\hline 64 & 271 & 177 & -18 & $5.0 \mathrm{E}-5$ & 184 & 3 & $6.4 \mathrm{E}-5$ & 183 & 3 & $6.2 \mathrm{E}-5$ \\
\hline 71 & 273 & -12 & 88 & 6.7E-4 & 169 & -9 & 4.7E-5 & 172 & -8 & $4.5 \mathrm{E}-5$ \\
\hline 72 & 281 & 203 & 14 & $3.9 \mathrm{E}-5$ & 142 & 12 & 7.4E-5 & 144 & 8 & 7.0E-5 \\
\hline 81 & 283 & 127 & -11 & $1.2 \mathrm{E}-4$ & 131 & -19 & $9.6 \mathrm{E}-5$ & 131 & -18 & $8.6 \mathrm{E}-5$ \\
\hline 82 & 294 & 150 & -17 & $6.4 \mathrm{E}-5$ & 156 & -21 & $6.2 \mathrm{E}-5$ & 158 & -24 & $5.2 \mathrm{E}-5$ \\
\hline 83 & 305 & 93 & 16 & $5.4 \mathrm{E}-5$ & 130 & -16 & $5.2 \mathrm{E}-5$ & 128 & -17 & $4.5 \mathrm{E}-5$ \\
\hline 84 & 316 & 59 & 30 & $2.2 \mathrm{E}-5$ & 140 & -34 & $2.2 \mathrm{E}-5$ & 142 & -38 & $2.0 \mathrm{E}-5$ \\
\hline 91 & 319 & 28 & 62 & 7.2E-5 & 82 & 47 & $2.2 \mathrm{E}-5$ & 100 & 29 & $1.7 \mathrm{E}-5$ \\
\hline 92 & 329 & 85 & 67 & $4.5 \mathrm{E}-5$ & 148 & 5 & $3.8 \mathrm{E}-5$ & 154 & -2 & $3.5 \mathrm{E}-5$ \\
\hline 93 & 339 & -2 & 53 & $5.5 \mathrm{E}-5$ & 41 & 61 & $1.4 \mathrm{E}-5$ & 41 & 56 & $1.3 \mathrm{E}-5$ \\
\hline 94 & 349 & 17 & 75 & $6.3 \mathrm{E}-5$ & 140 & 34 & $2.5 \mathrm{E}-5$ & 162 & 26 & $2.2 \mathrm{E}-5$ \\
\hline 101 & 352 & 101 & -26 & $5.4 \mathrm{E}-5$ & 159 & 15 & $4.5 \mathrm{E}-5$ & 153 & 3 & $4.1 \mathrm{E}-5$ \\
\hline 102 & 362 & 81 & 76 & $5.2 \mathrm{E}-5$ & 131 & 33 & $2.0 \mathrm{E}-5$ & 150 & 17 & $1.5 \mathrm{E}-5$ \\
\hline 103 & 372 & 67 & 79 & 7.7E-5 & 139 & -1 & $2.6 \mathrm{E}-5$ & 137 & -6 & $3.2 \mathrm{E}-5$ \\
\hline 104 & 382 & 178 & 11 & 4.7E-5 & 179 & -16 & 4.7E-5 & 186 & -21 & 4.7E-5 \\
\hline 111 & 385 & 170 & 24 & $5.5 \mathrm{E}-5$ & 165 & -3 & $4.9 \mathrm{E}-5$ & 165 & -2 & $4.5 \mathrm{E}-5$ \\
\hline 112 & 396 & 159 & -12 & 3.7E-5 & 156 & -30 & $3.5 \mathrm{E}-5$ & 157 & -29 & $3.3 \mathrm{E}-5$ \\
\hline 113 & 407 & 184 & -10 & $3.9 \mathrm{E}-5$ & 174 & -32 & $4.8 \mathrm{E}-5$ & 172 & -32 & $4.5 \mathrm{E}-5$ \\
\hline
\end{tabular}




\begin{tabular}{|c|c|c|c|c|c|c|c|c|c|c|}
\hline \multirow{2}{*}{$\begin{array}{l}\text { Sample } \\
\text { Number }\end{array}$} & \multirow{2}{*}{$\begin{array}{r}\text { Depth } \\
\mathrm{cm}\end{array}$} & \multicolumn{3}{|c|}{ Natural } & \multicolumn{3}{|c|}{$10 \mathrm{mT}$} & \multicolumn{3}{|c|}{$15 \mathrm{mT}$} \\
\hline & & Dec. & Inc. & Int. & Dec. & Inc. & Int. & Dec. & Inc. & Int. \\
\hline 121 & 420 & -37 & -30 & $2.4 \mathrm{E}-5$ & -70 & -57 & $1.2 \mathrm{E}-5$ & -49 & -54 & $1.0 \mathrm{E}-5$ \\
\hline 122 & 431 & 228 & 52 & $2.5 \mathrm{E}-5$ & 214 & 25 & $1.4 \mathrm{E}-5$ & 208 & 18 & $1.1 \mathrm{E}-5$ \\
\hline 123 & 439 & -44 & 55 & $3.1 \mathrm{E}-5$ & 249 & 16 & $1.1 \mathrm{E}-5$ & 266 & 16 & $1.1 \mathrm{E}-5$ \\
\hline 124 & 451 & 126 & 3 & $2.1 \mathrm{E}-5$ & 145 & -32 & $2.2 \mathrm{E}-5$ & 142 & -36 & $1.9 \mathrm{E}-5$ \\
\hline 131 & 453 & 211 & 7 & $1.6 \mathrm{E}-5$ & 136 & -38 & $9.8 \mathrm{E}-6$ & 164 & -55 & $9.8 \mathrm{E}-6$ \\
\hline 132 & 463 & 172 & 37 & $1.5 \mathrm{E}-5$ & 144 & -43 & $2.4 \mathrm{E}-5$ & 147 & -40 & $1.9 \mathrm{E}-5$ \\
\hline 133 & 472 & 69 & -21 & $9.3 \mathrm{E}-6$ & 149 & -46 & $1.6 \mathrm{E}-5$ & 152 & -50 & $1.6 \mathrm{E}-5$ \\
\hline 134 & 481 & 263 & 19 & $5.4 \mathrm{E}-6$ & 167 & -32 & $1.3 \mathrm{E}-5$ & 177 & -28 & $1.2 \mathrm{E}-5$ \\
\hline 141 & 484 & 115 & 8 & $1.9 \mathrm{E}-5$ & 183 & -35 & $1.4 \mathrm{E}-5$ & 174 & -40 & $1.1 \mathrm{E}-5$ \\
\hline 142 & 493 & 189 & -6 & $7.2 \mathrm{E}-5$ & 188 & -19 & $5.8 \mathrm{E}-5$ & 192 & -22 & $5.1 \mathrm{E}-5$ \\
\hline 143 & 503 & 176 & 62 & $2.1 \mathrm{E}-5$ & 158 & 23 & $9.6 \mathrm{E}-6$ & 163 & 20 & $8.2 \mathrm{E}-6$ \\
\hline 144 & 512 & 68 & 35 & $1.3 \mathrm{E}-5$ & 186 & -36 & $6.3 \mathrm{E}-6$ & 175 & -36 & $6.6 \mathrm{E}-6$ \\
\hline 151 & 514 & -19 & 40 & $3.4 \mathrm{E}-5$ & -39 & 15 & $8.3 \mathrm{E}-6$ & -15 & 15 & $5.9 \mathrm{E}-6$ \\
\hline 152 & 525 & 41 & 70 & 4.7E-5 & 139 & 66 & $1.8 \mathrm{E}-5$ & 146 & 60 & $1.6 \mathrm{E}-5$ \\
\hline 153 & 535 & -6 & 46 & $8.1 \mathrm{E}-5$ & -4 & 33 & $3.3 \mathrm{E}-5$ & -7 & 36 & $2.6 \mathrm{E}-5$ \\
\hline 154 & 545 & 189 & 33 & $1.2 \mathrm{E}-4$ & 185 & 21 & $1.1 \mathrm{E}-4$ & 182 & 21 & $1.1 \mathrm{E}-4$ \\
\hline 161 & 547 & 173 & 57 & $2.8 \mathrm{E}-5$ & 186 & 2 & $2.4 \mathrm{E}-5$ & 187 & -0 & $2.4 \mathrm{E}-5$ \\
\hline 162 & 558 & 208 & 7 & $2.6 \mathrm{E}-5$ & 200 & -28 & $3.8 \mathrm{E}-5$ & 201 & -28 & $3.2 \mathrm{E}-5$ \\
\hline 163 & 568 & 10 & 68 & $1.7 \mathrm{E}-5$ & 206 & -25 & $9.1 \mathrm{E}-6$ & 211 & -33 & 1.1E-5 \\
\hline 171 & 570 & 146 & 73 & $4.4 \mathrm{E}-5$ & 175 & 27 & $2.9 \mathrm{E}-5$ & 173 & 31 & 2.7E-5 \\
\hline 172 & 580 & 255 & 54 & $10.0 \mathrm{E}-6$ & 190 & -46 & $1.5 \mathrm{E}-5$ & 176 & -43 & $1.6 \mathrm{E}-5$ \\
\hline 173 & 591 & 131 & 63 & $4.3 \mathrm{E}-5$ & 161 & 14 & $2.1 \mathrm{E}-5$ & 160 & 10 & $2.2 \mathrm{E}-5$ \\
\hline 174 & 601 & 39 & 67 & $2.2 \mathrm{E}-5$ & 148 & 14 & $6.4 \mathrm{E}-6$ & 150 & 2 & $7.4 \mathrm{E}-6$ \\
\hline 181 & 603 & 92 & 52 & $7.9 \mathrm{E}-6$ & 163 & -18 & $6.4 \mathrm{E}-6$ & 135 & -31 & $4.9 \mathrm{E}-6$ \\
\hline 182 & 613 & 2 & 69 & $2.6 \mathrm{E}-5$ & 152 & 87 & $1.2 \mathrm{E}-5$ & 113 & 78 & $8.2 \mathrm{E}-6$ \\
\hline 183 & 624 & -44 & 19 & 2.1E-5 & -69 & -45 & $1.7 \mathrm{E}-5$ & -67 & -53 & $1.4 \mathrm{E}-5$ \\
\hline 184 & 634 & -16 & 5 & 1.6E-5 & 267 & -55 & 1.1E-5 & -86 & -59 & 8.6E-6 \\
\hline 191 & 636 & 106 & 60 & $2.0 \mathrm{E}-6$ & 112 & -37 & $3.0 \mathrm{E}-6$ & 160 & 1 & $1.4 \mathrm{E}-6$ \\
\hline 192 & 646 & -38 & 7 & $2.3 \mathrm{E}-5$ & -54 & -26 & $1.8 \mathrm{E}-5$ & -55 & -40 & $1.2 \mathrm{E}-5$ \\
\hline 193 & 657 & 2 & 47 & $2.6 \mathrm{E}-5$ & -4 & 19 & $5.7 \mathrm{E}-6$ & -26 & -27 & $3.0 \mathrm{E}-6$ \\
\hline 194 & 667 & 14 & 64 & $4.3 \mathrm{E}-5$ & 42 & 63 & $1.6 \mathrm{E}-5$ & 45 & 61 & $1.1 \mathrm{E}-5$ \\
\hline 201 & 669 & 8 & 45 & $4.5 \mathrm{E}-5$ & 25 & 43 & $2.5 \mathrm{E}-5$ & 24 & 45 & $1.6 \mathrm{E}-5$ \\
\hline 202 & 677 & 22 & 84 & $5.0 \mathrm{E}-5$ & 183 & 84 & $2.6 \mathrm{E}-5$ & 192 & 80 & $1.8 \mathrm{E}-5$ \\
\hline 203 & 685 & 48 & 52 & $3.3 \mathrm{E}-5$ & 74 & 50 & $1.7 \mathrm{E}-5$ & 78 & 44 & $1.2 \mathrm{E}-5$ \\
\hline 204 & 692 & 25 & 48 & $1.9 \mathrm{E}-5$ & 56 & 25 & $6.3 \mathrm{E}-6$ & 78 & -17 & $1.6 \mathrm{E}-6$ \\
\hline
\end{tabular}

however, the declination of the deeper samples at Hole 5 have greater variability than those of shallower samples (Fig. 5). Additionally, the polarity results from Hole 5 are shown in Fig. 6, which also shows the correlation with the known paleomagnetic record and stratigraphy of the cave sediments.

\section{Criteria For Reversal Assignment}

Sequences of samples that had an average declination of $\sim 0.0^{\circ}$ and an average inclination of $\sim 35.0^{\circ}$ were assigned to normal polarity. The ideal inclination for DRM in the Manitou Springs area should be $\sim 60^{\circ}$. The low values recorded at Cave of the Winds are considered to be the 


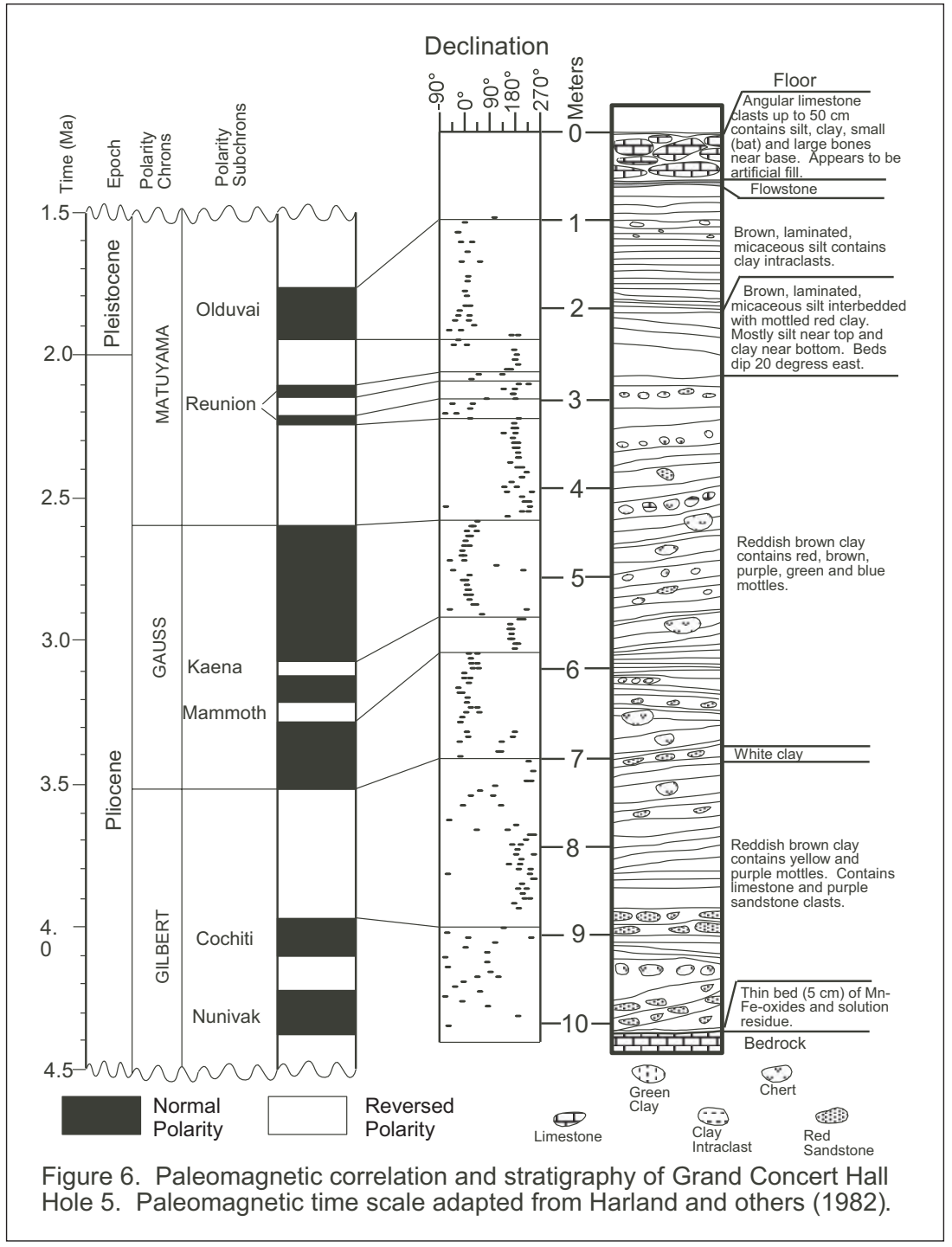

samples is that these samples were compacted and dewatered during a normal polarity interval, overprinting a normal component. The dewatering and compaction may have occurred rather quickly following rapid draining of the water in the cave passages related to downcutting by Fountain Creek. Mud cracks present in the top two meters of the sediments at the Grand Concert Hall combined with their mostly normal polarity (Fig. 6) indicate that this is a plausible explanation. Further micro-sampling and precision analysis would be necessary to ascertain the mechanism responsible for the difference in the inclinations.

Chemical remanent magnetization (CRM) may also be a contributing factor to the inclination anomalies. Alteration and oxidation of iron-bearing minerals in the sediments may contribute to the CRM. This could only be a factor in the top two meters of coarse sediments (Fig. 6 ), which contain unaltered minerals; because the general oxidizing conditions and neutral to slightly alkaline $\mathrm{pH}$ of percolating cave waters through these sediments would preclude mobilization or precipitation of iron oxides. The underlying soil-derived clays, which have already undergone prolonged oxida-

result of inclination error resulting from sediment compaction (Verosub, 1977). Sequences of samples that had an average declination of $\sim 180^{\circ}$ were assigned a reversed polarity. In most cases, inclinations of these samples were variable, ranging mostly between $-35.0^{\circ}$ and $+10.0^{\circ}$. Because of this variability, the sample declinations were used to determine reversals (Fig. 5). These anomalous inclinations appear to be related to post-depositional acquisition of remanent magnetization.

\section{Effects Of Post-Depositional Remanent Magnetization On Sediments}

Most post-depositional remanent magnetization (PDRM) is the result of realignment of the magnetic particles during compaction and especially dewatering, both of which can take place thousands to millions of years after deposition (Verosub, 1977). A possible explanation of the variability of the inclination of the reversed tion before being deposited in the cave, are chemically stable and would not be vulnerable to CRM.

\section{Paleomagnetic Correlation}

Because there are no independent dates on the cave sediments, correlation of the magnetic polarity record of the Cave of the Winds sediments with the accepted polarity time scale is difficult. It requires matching the sequence of known polarity events with the Cave of the Winds record. The age of the Nussbaum Alluvium, which is apparently related to the uppermost coarse cave sediments, however, can be used to help constrain the paleomagnetic correlation. The relationship of the Nussbaum Alluvium to the detrital sediments in Cave of the Winds will be discussed in detail.

As discussed previously, the clay is deposited in the cave below the phreatic-vadose interface where sediment-laden streams enter water-filled passages. The 


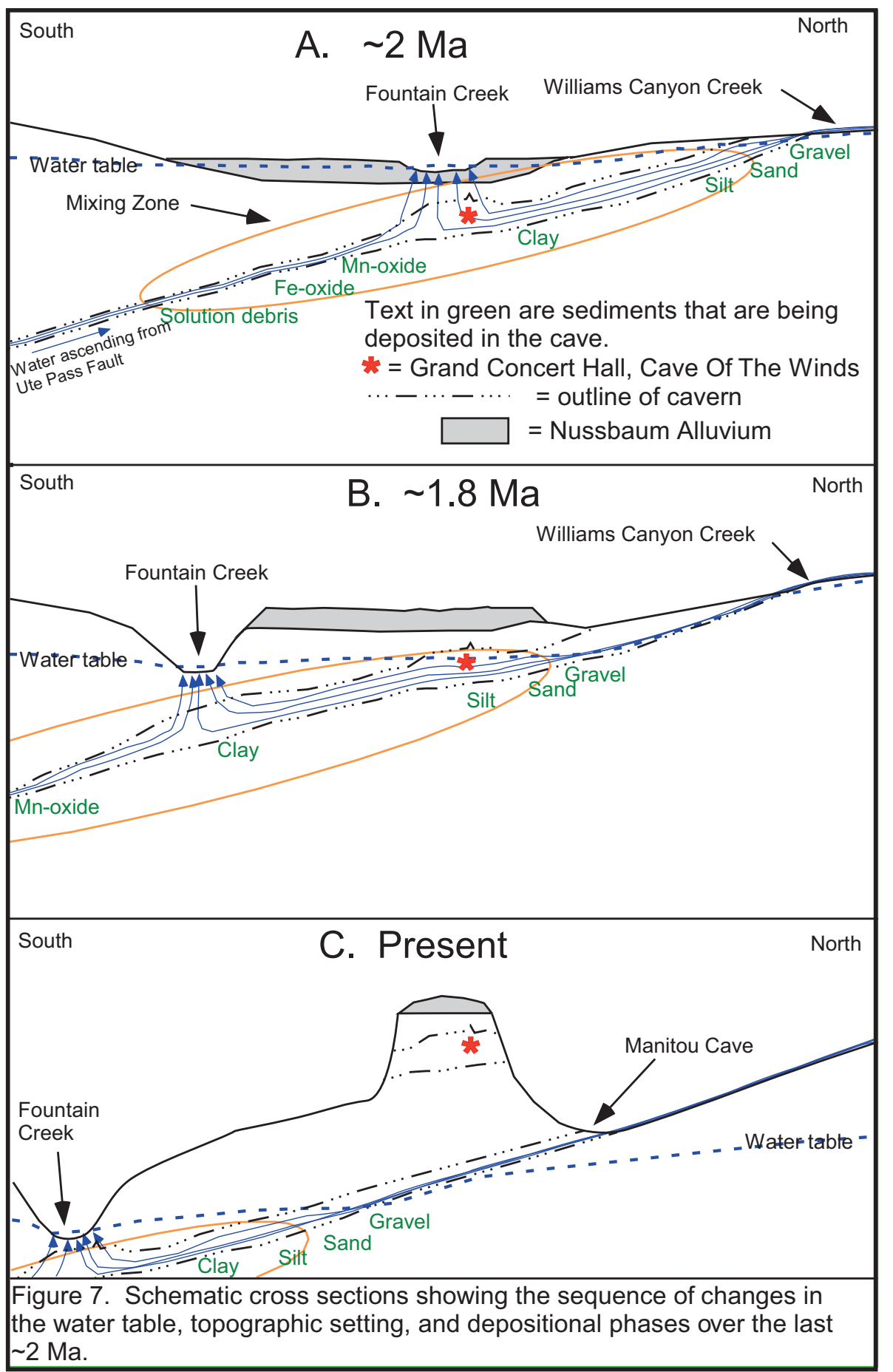

ergy changed the sedimentation regime from clay deposition to silt, sand, and gravel deposition (Fig. 7B). Fluvial sedimentation at Cave of the Winds stopped as Fountain Creek moved further to the south and downcut further (Fig. 7C). The relationship between the Nussbaum Alluvium and the sediments in the cave indicate that the siltclay interface in the Grand Concert Hall took place after the Nussbaum was deposited. More specifically, the siltclay interface should be the same age as the Nussbaum Alluvium minus the time it took for Fountain Creek to downcut and drop the water table to the level of the Grand Concert Hall (Fig. 7B).

The sediment floor of the Grand Concert Hall, where the paleomagnetic data was obtained, is about $20 \mathrm{~m}$ below the Nussbaum Alluvium. The age of the Nussbaum Alluvium ( 1.9 $\mathrm{Ma})$ and its height above modern streams $(200 \mathrm{~m})$ provides an estimate of the average down-cutting rate of $10.5 \mathrm{~cm} / 1000$ years. Accordingly, accumulation of coarse sediments in the cave $20 \mathrm{~m}$ below the Nussbaum Alluvium probably would have begun $\sim 1.7 \mathrm{Ma}$.

The estimated $1.7 \mathrm{Ma}$ age of the clay-coarse sediment interface correlates well with the onset of the Olduvai Subchron at $1.9 \mathrm{Ma}(\sim 2.2 \mathrm{~m}$

Nussbaum Alluvium was being deposited at the same time that clay was being deposited in the Grand Concert Hall the (Fig. 7A). As Fountain Creek downcut and moved to the south, the water table dropped (Fig. 7B). The drop in the water table coincided with drop in the water depth in rooms like the Grand Concert Hall. As the water depth dropped, the velocity of the water passing through the room increased. The increased stream en- depth, Fig. 6). This is the most probable correlation. Alternatively, one could match the normal-polarity sequence (1.0 to $2.2 \mathrm{~m}$ depth, Fig. 6) with the Jaramillo Subchron (Harland et al., 1982) or the Gauss Chron (Fig. 6). These correlations, however, would result in an age of $\sim 1.0 \mathrm{Ma}$ or $\sim 2.6 \mathrm{Ma}$, respectively, for the clay-coarse-sediment interface, which is estimated to be $1.7 \mathrm{Ma}$, thereby making these alternate correlations unlikely. 
The complete paleomagnetic correlation shown on Fig. 6 follows from correlation of the normal-polarity interval between 1.0 and $2.2 \mathrm{~m}$ in depth with the Olduvai Subchron. According to the correlation suggested here, the oldest cave sediment was deposited about $4.3 \mathrm{Ma}$, a date that agrees quite well with the previously discussed probable age of the major onset of cave formation (7 Ma to $4 \mathrm{Ma}$ ).

\section{CONCLUSIONS}

Cave of the Winds is a phreatic cave dissolved from the calcite-rich Manitou, Williams Canyon, and Leadville Formations. Dissolution occurred along joints associated with Laramide faulting and folding. Paleokarst features, such as sediment-filled fissures and caves, indicate that some of the passages at Cave of the Winds are related to cave-forming episodes that started soon after the deposition of the Ordovician Manitou Formation and continued to the beginning of the Cretaceous Laramide Orogeny. Most speleogenesis, however, occurred in the last $\sim 5.0 \mathrm{Ma}$.
The Nussbaum Alluvium was assigned an age of $\sim 1.9$ Ma by means of aminostratigraphy. The age of the Nussbaum Alluvium and its relation to coarse grained sediments at Cave of the Winds were used to fix an age of $\sim 1.7 \mathrm{Ma}$ for the onset of coarse grained sedimentation in the cave. This enabled the identification of the Olduvai Polarity Subchron in the coarse grained sediments. Correlation of the magnetostratigraphy of cave sediments with the accepted polarity time scale indicates that the dissolution of cave passage started $\sim 4.2 \mathrm{Ma}$ and stopped $\sim 1.5 \mathrm{Ma}$.

\section{REFERENCES}

Blanton, T. L., 1973: The Cavern Gulch Faults and the Fountain Creek Flexure, Manitou Spur, Colorado [M.S. thesis]: Syracuse University, New York, 90 p.

Bianchi, L., 1967: Geology of the Manitou-Cascade Area, El Paso County, Colorado with a study of the permeability of Its crystalline rocks [M.S. Thesis]: Golden, Colorado School of Mines.

Cande, S. C., and D. Kent., 1992: A new geomagnetic polarity time scale for the Late Cretaceous and Cenozoic: Journal of Geophysical Research, 97, 10, 13- 17.

Epis, R. C., and C.E. Chapi, 1975: Geomorphic and tectonic implications of the Post-Laramide, Late Eocene Erosion surface in the Southern Rocky Mountains, in Curtis, B.F., ed., Cenozoic History of the Southern Rocky Mountains: Geological Society of America Memoir 144, 45-74.

Fish, L., 1988: The real story of how Cave of the Winds Formed: Rocky Mountain Caving, 5, 2, 16-19.

Forster, J. R., 1977: Middle Ordovician subaerial exposure and deep weathering of the Lower Ordovician Manitou Formation along the Ute Pass Fault zone: Geological Society of America Abstracts with Programs, 9, 722.

Goodfriend, G. A., 1987: Evaluation of amino-acid racemization/epimerization dating using radiocarbondated fossil land snails: Geology 15, 698-700.
Hailwood, E. A., 1989: The role of magnetostratigraphy in the development of geological time scales; Paleoceanography, 4, 1, 1-18.

Hamil, M. M., 1965: Breccias of the Manitou Springs area, Colorado [M.S. thesis]: Louisiana State University, $43 \mathrm{p}$.

Harland, W. B., et al., 1982: A geologic time scale: Cambridge, Great Britain, Cambridge University Press, $66 \mathrm{p}$.

Hose, L. D., \& Esch, C. J., 1992: Paleo-cavity fills formed by upward injection of clastic sediments to lithostatic load: exposures in Cave of the Winds, Colorado [abs.]: National Speleological Society Convention Program, Salem, Indiana, p.50

Izett, G. A., Obradovich, J. D., \& H.H. Mehnert., 1989: The Bishop Ash Bed (Middle Pleistocene) and some older (Pliocene and Pleistocene) chemically and mineralogically similar ash beds in California, $\mathrm{Ne}$ vada, and Utah: U. S. Geological Survey Bulletin, $1675,37 \mathrm{p}$.

Luiszer, F. G., 1997: Genesis of Cave of the Winds, Manitou Springs, Colorado, [Ph. D. thesis]: Boulder, University of Colorado, $112 \mathrm{p}$.

Machette, M. M., 1975: The Quaternary geology of the Lafayette Quadrangle, Colorado, [M. S. thesis]: Boulder, University of Colorado, 83 p. 
Mankinen, E. A., \& Dalrymple, G. B., 1979: Revised geomagnetic polarity time scale for the interval $0-5 \mathrm{~m}$. y. B. P.; Journal of Geophysical Research, 84, B2, 615-626.

Miller, G. H., \& Brigham-Grette, J., 1989: Amino acid geochronology: Resolution and precision in carbonate fossils in INQUA Quat. Dating Methods, Rutter and Brigham-Grette Eds. Pergamon Press.

Mitterer, R. M., \& Kriausakul, 1989: Calculation of amino acid racemization ages based on apparent parabolic kinetics: Quaternary Science Reviews, 8, 353-357.

Morgan, G. B., 1950: Geology of Williams Canyon area, north of Manitou Springs, El Paso County, Colorado (Masters thesis): Golden, Colorado School of Mines, $80 \mathrm{p}$.

Mutschler, F. E., Larson, E. E., \& R.M. Bruce: 1987: Laramide and younger magmatism in Colorado-New petrologic and tectonic variations on old themes: Colorado School of Mines Quarterly $82,4,1-47$.

Sawyer, D. A. et al., 1995: New chemical criteria for Quaternary Yellowstone tephra layers in central and western North America: Geological Society of America Abstracts with Programs, 27, 6, 109.

Scott, G. R., 1963, Nussbaum Alluvium of Pleistocene(?) age at Pueblo, Colorado. U. S. Geological Survey Professional Paper, 475-C, C49-C52

Scott, G. R., 1975, Cenozoic surfaces and deposits in Curtis, B. F., ed., Cenozoic History of the Southern Rocky Mountains: Geological Society of America Memoir 144, 227-248.
Soister, E., 1967, Relation of Nussbaum Alluvium (Pleistocene) to the Ogallala Formation (Pliocene) and to the Platte-Arkansas divide, Southern Denver Basin, Colorado. U. S. Geological Survey Professional Paper 575-D, p.D39-D46.

Szabo, B. J., 1980, Results and assessment of uraniumseries dating of vertebrate fossils from Quaternary alluviums in Colorado: Arctic and Alpine Research, 12, 95-100.

Tarling, D. H., 1983, Palaeomagnetism; principles and applications in geology, geophysics and archaeology: Chapman and Hall Ltd., London, 379 p.

Trimble, D. E., \& Machette, M. M., 1979, Geologic map of the Colorado Springs-Castle Rock Area, Front Range Urban Corridor, Colorado; U. S. Geological Survey, 1:100,000, Map I-857-F

Tweto, O., 1975, Laramide (Late Cretaceous-Early Tertiary) Orogeny in the Southern Rocky Mountains in Curtis, B.F., ed., Cenozoic History of the Southern Rocky Mountains: Geological Society of America Memoir 144, 1-44.

Verosub, K. L., 1977, Depositional and post-depositional processes in the magnetization of sediments: Reviews of Geophysics and Space Physics, 15, 129143. 



\title{
HOW LONG DOES EVOLUTION OF THE TROGLOMORPHIC FORM TAKE? ESTIMATING DIVERGENCE TIMES IN ASTYANAX MEXICANUS
}

\author{
KAKO DOLGO TRAJA EVOLUCIJA TROGLOMORFNIH OBLIK? \\ OCENJEVANJE DIVERGENČNIH ČASOV PRI ASTYANAX \\ MEXICANUS
}

\author{
Megan L. PORTER ${ }^{1}$, Katharina DITTMAR ${ }^{2}$ \& Marcos PÉREZ-LOSADA ${ }^{3}$
}

\begin{abstract}
UDC 551.44:597

591.542

Megan L. Porter, Katharina Dittmar \& Marcos Pérez-Losada: How long does evolution of the troglomorphic form take? Estimating divergence times in Astyanax mexicanus

Features including colonization routes (stream capture) and the existence of both epigean and cave-adapted hypogean populations make Astyanax mexicanus an attractive system for investigating the subterranean evolutionary time necessary for acquisition of the troglomorphic form. Using published sequences, we have estimated divergence times for A. mexicanus using: 1) two different population-level mitochondrial datasets (cytochrome $\mathrm{b}$ and NADH dehydrogenase 2) with both strict and relaxed molecular clock methods, and 2) broad phylogenetic approaches combining fossil calibrations and with four nuclear (recombination activating gene, seven in absentia, forkhead, and $\alpha$-tropomyosin) and two mitochondrial (16S rDNA and cytochrome b) genes. Using these datasets, we have estimated divergence times for three events in the evolutionary history of troglomorphic A. mexicanus populations. First, divergence among cave haplotypes occurred in the Pleistocene, possibly correlating with fluctuating water levels allowing the colonization and subsequent isolation of new subterranean habitats. Second, in one lineage, A. mexicanus cave populations experienced introgressive hybridization events with recent surface populations (0.26-2.0 Ma), possibly also correlated with Pleistocene events. Finally, using divergence times from surface populations in the lineage without evidence of introgression as an estimate, the acquisition of the troglomorphic form in A. mexicanus is younger than 2.2 (fossil calibration estimates) - 5.2 (cytb estimate) Ma (Pliocene).
\end{abstract}

Key words: Astyanax mexicanus, divergence time, troglomorphy, subterranean, evolution.
Izvleček

UDK 551.44:597

591.542

Megan L. Porter, Katharina Dittmar \& Marcos Pérez-Losada: Kako dolgo traja evolucija troglomorfnih oblik? Ocenjevanje divergenčnih časov pri Astyanax mexicanus

Značilnosti, ki vključujejo tudi kolonizacijske poti in obstoj tako epigejičnih kot hipogejičnih populacij vrste Astyanax mexicanus, ji omogočajo, da predstavlja zanimiv sistem za proučevanje evolucije in časa, potrebnega za razvoj podzemeljskih troglomorfnih oblik. Za A. mexicanus smo na podlagi že objavljenih sekvenc ocenili divergenčni čas ob uporabi: 1) dveh različnih populacijskih mitohondrialnih podatkovnih baz (citokrom $\mathrm{b}$ in NADH dehidrogenaze 2), obe $\mathrm{z}$ natančno in sproščeno metodo molekularne ure, in 2) razširjenega filogenetskega pristopa $\mathrm{v}$ kombinaciji s fosilno kalibracijo ter štirimi jedrnimi geni (rekombinacijski aktivacijski gen, "forkhead kontrolni gen" in $\alpha$-tropomiozin) in dvema mitohondrialnima genoma (16S rDNA in citokrom b). Ob uporabi navedenih podatkovnih baz smo ocenili divergenčni čas za tri dogodke v zgodovini razvoja troglomorfnih populacij A. mexicanus. Prvič, razhajanje med podzemeljskimi haplotipi se je zgodilo v Pleistocenu, verjetno v odvisnosti od nihanja vode, ki je omogočilo kolonizacijo in posledično izolacijo v novih podzemeljskih habitatih. Drugič, verjetno je $\mathrm{v}$ povezavi s pleistocenskimi dogodki pri eni liniji podzemeljskih populacij $A$. mexicanus prišlo do introgresivne hibridizacije s takratnimi površinskimi populacijami $(0.26-2.0$ Ma). Z uporabo divergenčnega časa površinskih populacij tistih linij, ki ne kažejo introgresije ocenjujemo, da je troglomorfna oblika A. mexicanus mlajša od 2,2 (ocene fosilne kalibracije) do 5,2 milijona let (cytb ocena) (Pliocen).

Ključne besede: Astyanax mexicanus, divergenčni čas, troglomorfizem, podzemlje, speleobiologija, evolucija.

\footnotetext{
${ }^{1}$ Dept. of Biological Sciences, University of Maryland Baltimore County, Baltimore, MD, USA; e-mail: porter@umbc.edu

${ }^{2}$ Dept. of Molecular Biology, University of Wyoming, Laramie, WY, USA

${ }^{3}$ GENOMA LLC, 50E Woodland Hills, Provo, UT 84653-2052, USA
}

Received/Prejeto: 06.12.2006 